\title{
Correction to: The Surco canal, an ancient irrigation canal in Lima, Peru, and a citizens' campaign for its protection
}

\author{
Javier Lizarzaburu ${ }^{1}$ (D) \\ Published online: 13 February 2021 \\ (c) Springer Nature B.V. 2021
}

\section{Correction to: Water History (2020) 12:299-310 https://doi.org/10.1007/s12685-020-00257-1}

In the original publication of this article, the Acknowledgement section and Author Information were missing and are given below.

Acknowledgments The campaign, the research and the publication of the book were funded by the Surco-Huatica Commission. My gratitude to them and its then president, Luis Molina.

Special thanks to the members of the Advisory Council who gave their support during the campaign:

- José Canziani, architect, expert in the pre-Hispanic period, PUCP-Catholic University of Peru.

- Luis Jaime Castillo, archaeologist, former Culture Minister (then former vice Minister).

- Patricia Ciriani, art historian and cultural manager.

- Álvaro Higueras, archaeologist.

- Elmer Linares, agronomist.

- Denise Pozzi-Escot, archaeologist, director of the Sanctuary of Pachacamac.

- In particular, to Joaquín Narváez, archaeologist, PhD in Lima's canals.

And to the team of professionals at the Ministry of Culture of Peru who worked hard for the declaration of the Surco canal as national heritage.

Publisher's Note Springer Nature remains neutral with regard to jurisdictional claims in published maps and institutional affiliations.

The original article can be found online at https://doi.org/10.1007/s12685-020-00257-1.

Javier Lizarzaburu

Jlizarzaburu.montani@gmail.com; c.j.lizarzaburumontani@student.vu.nl

1 Vrije Universiteit, Amsterdam, The Netherlands 
Javier Lizarzaburu Javier Lizarzaburu is a communications and heritage specialist from Peru. In 2010 he created the concept Millenary Lima, and in 2016 launched a campaign to secure National Cultural Heritage status for the Surco canal. He has worked for the BBC in London and studied Communication Sciences at the University of Lima and Postgraduate studies at the Autonomous University of Barcelona. In September 2020 he started an MA in Heritage Studies at the Vrije University of Amsterdam. Javier is interested in city, citizenship and cultural heritage issues. 